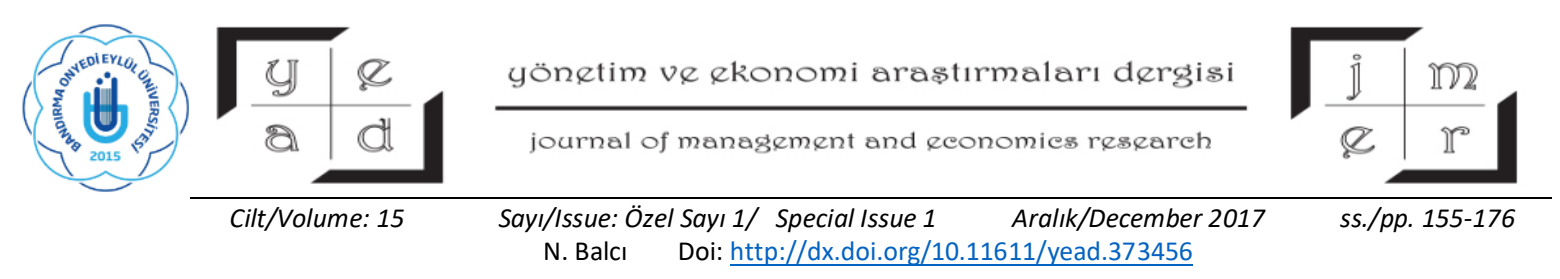

\title{
FINANCIAL PERFORMANCE ANALYSIS WITH TOPSIS TECHNIQUE: A CASE STUDY OF PUBLIC UNIVERSITY HOSPITALS IN TURKEY ${ }^{1}$
}

\author{
Araş. Gör. Nehir BALCI*
}

\begin{abstract}
Financial performance of public university hospitals is frequently discussed today and an overall analysis is required because data resources of hospitals are limited and their specific structures make financial performance assessments difficult. In this respect, the present study carried out a performance analysis using TOPSIS technique in order to help decision makers in the health care system to make better decisions. The study examined the financial performances of 27 public university hospitals which were available in Audit Reports of the Turkish Court of Accounts between the years 2014 and 2015, considering eight financial ratios. As a result, the ranking of hospitals having the best and the worst performance changed dramatically each year. However, it is seen that Atatürk University Hospital remained among those hospitals with the highest three performances hospitals whereas Hacettepe University Hospital had one of the lowest three performances during the study period.
\end{abstract}

Keywords: Public University Hospitals, Financial Performance, Financial Analysis of Health Organizations, TOPSIS

JEL Classification: I11, I18, C44

\section{TOPSIS TEKNIIĞi ILE FINANSAL PERFORMANS ANALİİ: TÜRKIYYE'DEKİ DEVLET ÜNIVERSITESİ HASTANELERİNIN ÖRNEK BİR İNCELEMESI}

\section{ÖZ}

Devlet üniversitesi hastanelerinin finansal performansı günümüzde slkllkla tartışlmakla birlikte hastanelerle ilgili veri kaynaklarının klsitl olması ve özellikli yapılarının finansal performans değerlendirmesini zorlaştırılması genel bir analiz yapmayı gerektirmektedir. Bu bağlamda, bu

\footnotetext{
${ }^{1}$ The first draft of this paper is presented ICOAEF 2017 conference on 06-07 December

* Dokuz Eylül Üniversitesi, Seferihisar Fevziye Hepkon Uygulamalı Bilimler Yüksekokulu, Uluslararası Ticaret Bölümü, nehir.balci@deu.edu.tr
} 
Yönetim ve Ekonomi Araștırmaları Dergisi / Journal of Management and Economics Research

Cilt/Volume: 15 Sayı/Issue: Özel Sayı 1/Special Issue 1 Aralık/December 2017 ss./pp. 155-176 N. Balcı Doi: http://dx.doi.org/10.11611/yead.373456

çalışmada sağlık sistemi karar vericilerine daha iyi karar vermede yardımcı olmak amacıyla TOPSIS yöntemini kullanarak bir performans analizi gerçekleştirilmiştir. Bu çalışmada, Sayıştay Denetim raporlarında yer alan 27 Devlet üniversitesi hastanesinin 2014-2015 yllları arasinda finansal performanslarl, sekiz oran göz önünde bulundurularak incelenmiştir. Sonuç olarak, en yüksek ve en düşük performansı gösteren üniversite hastanelerinin sıralaması yıllar itibariyle büyük ölçüde değişiklik göstermektedir. Fakat çalı̧̧ma süresi boyunca, Atatürk Üniversite Hastanesi en yüksek performansa sahip üç hastane arasindayken Hacettepe Üniversite Hastanesinin en düşük performansa sahip üç hastane arasında olduğu tespit edilmiştir.

Anahtar Kelimeler: Devlet Üniversitesi Hastaneleri, Finansal Performans, Sağllk İsletmelerinde Finansal Analiz, TOPSIS

JEL Sinıflandırması: I11, I18, C44

\section{INTRODUCTION}

Health care services are among the most important indicators of development in socio-economic terms. It is an approved fact that health care services includes not only the responsibility to preserve and improve people's health but also to protect individuals from financial risks to offer treatment when confront with any disease (Öztürk \& Uçan, 2017). Therefore, the health care industry is one of the fields that is often intervened by the public sector. In Turkey, public health care services at different organizations and institutions offer various health care levels of based on the scope of diagnosis, curative and preventive care services. Primary and preventive health care institutions (first health care level) are family medicine centers, secondary health care level institutions are public hospitals and third health care level institutions are hospitals under the Ministry of Health and university hospitals. The fact that university hospitals are both training and research institutions where investigation on treatment cases requiring special knowledge and skills are conducted. Therefore, it distinguishes them from other hospitals and brings into attention the need for studying their financial sustainability.

The first prerequisite for financial sustainability is to balance income and expenses of institute or organization. The amount of revenues generated and the average cost per patient by university hospitals in 2009 were 2.962 million TL and 179 TL respectively. In 2014 with an increase of 134\%, the amount of revenue generated went up to 6.944 million TL and the average costs per patient reached 180 TL with a $0.5 \%$ increase. Among the $2^{\text {nd }}$ health care level, $3^{\text {rd }}$ health care level university and private hospitals which are offering health care services, the highest average costs belong to university hospitals. Some of the reasons underlying the high average cost at university hospitals may be listed as a) the complicated structure of the health care services offered at these institutions; b) the high number of the skilled labor 
Yönetim ve Ekonomi Araștırmaları Dergisi / Journal of Management and Economics Research

Cilt/Volume: 15 Sayı/Issue: Özel Sayı 1/Special Issue 1 Aralık/December 2017 ss./pp. 155-176 N. Balcı Doi: http://dx.doi.org/10.11611/yead.373456

due to being an educational institution; c) the dramatic increase in the number of patient visits to university hospitals and the fixed rate policy; and d) bundle pricing that have been used in university hospitals for the last 9 years (Gülşen \& Yıldıran, 2017).

It is seen that recently the number of studies carried out on university hospitals has been on a gradual rise in Turkey. Studies concerning the financial structures of hospitals have revealed different findings on the financial activities and problems of hospitals. It has been found that internal and external factors are effecting the financial sustainability at university hospitals. The most significant external factor is the pay-back system and pricing, on the other hand the major internal factor is the inefficient use of staff, equipment and medical technology (Yiğit \& Yiğit, 2016). Similarly, it is stated that the pay-back system and Health Implementation Communiqué (SUT) ${ }^{2}$ affect the financial structure of university hospitals negatively and that paying for some services and consumables that are not included in the SUT by the hospital revolving fund instead of Social Security Institutions (SSI) brings along an additional burden on the financial structure (Gülşen \& Yıldıran, 2017). It has been found that the debts of university hospitals increase constantly as a natural result of all the above-mentioned factors (Türkmen, 2016).

University hospitals have a pivotal role in the health care system as they offer medical training, raise academicians, are the centers of scientific research and provide continuous health care services. This requires health policy implementers to act highly responsibly when making decisions. Thus, in order to implement accurate health care policies, financial performance of university hospitals must be followed carefully. In this respect, the financial performances in 2014 and 2015 of 27 public university hospitals included in the Reports of the Turkish Court of Audits were analyzed considering eight financial ratios. One of the frequently used methods in multiple criteria decision making (MCDM) problems, the TOPSIS (Technique for Order Preference by Similarity to Ideal Solution) was employed as the method of analyses. The distribution of the study is that in the first part of the study a review of the related literature is presented including an explanation of TOPSIS method used in performance assessment. This section is followed by displaying the implementation of TOPSIS methodology in public university hospitals and the finding are discussed; the study is concluded with discussion and recommendations.

\section{LITERATURE}

A performance assessment method, TOPSIS has a simple and understandable calculation technique, which allows for measuring the relative performance of each alternative over a single mathematical equation (Yeh, 2002). Since it makes decision making easiers, TOPSIS is used in many sectors.

\footnotetext{
${ }^{2}$ Health Implementation Communiqué abbreviated as SUT (Turkish translation is "Sağlık Uygulama Tebliği”).
} 
Yönetim ve Ekonomi Arastırmaları Dergisi / Journal of Management and Economics Research

Cilt/Volume: 15 Sayı/Issue: Özel Sayı 1/Special Issue 1 Aralık/December 2017 ss./pp. 155-176 N. Balcı Doi: http://dx.doi.org/10.11611/yead.373456

Currently, to my best knowledge none study in which TOPSIS analysis is used to evaluate public university hospitals; therefore, this section of the study includes examples of studies that used TOPSIS analysis in different fields in Turkey.

In order to develop a model to determine the performance of airline companies Akkaya (2004) has used financial and non-financial performance data of 2002 and carried out a grey relational analysis and TOPSIS analysis. As a result of the analyses, the initial 63 ratios specified for performance assessment were grouped and decreased to 13 ratios and it was recommended that the study should be repeated with different companies. In their study, Ömürbek et al. (2013) used the financial data obtained from the statements of the financial position and performance charts pertaining to 2012 of an airline transport company (ABC) operating in BIST and an airline transport company (XYZ) operating in Frankfurt Stock Exchange and made an evaluation of financial performances of both companies for the given year. Akgün \& Soy Temür (2013) used the TOPSIS method to evaluate the 6-year (2010-2015) financial performance of 2 airline transport companies in the İstanbul Stock Exchange transportation index.

In their study on the evaluation of the performance of economy in Turkey, Eleren \& Karagül (2008) determined a single performance score for each year with reference to 7 fundamental economic indicators within the 1986-2006 period using TOPSIS. They concluded that the best economic performance occurred in 1986 while the worst performance was seen in 1999 and they tried to reveal the performance changes in economy.

The study carried out on the banking sector in Turkey, Demireli (2010) examined the performances of state-owned banks operating in Turkey comparatively year by year and showed that common stateowned banks working nationwide are effected by national and global crises, their performance scores fluctuate constantly depending on foreign data and that no noticeable improvement has been made in banking sector. In their study on financial industry, Yayar \& Baykara (2012) measured the activities and efficiency of participation banks between 2005 and 2011 using TOPSIS technique. Ege, Topaloğlu \& Özyamanoğlu (2013) analyzed financial performance with TOPSIS method under 9 criteria while studying the relation between the financial performance and institutional administration scores of 18 companies listed in the Institutional Administration Index. In the study carried out by Taşabat, Cinemre \& Şen, (2015) financial performances of the deposit banks operating in the Turkish Banking Industry in 2013 were evaluated by weighting separately with three different weighting techniques known as "equal weight, scoring and Saaty's method" of WSA, MAPPAC, ORESTE, PROMETHEE, VIKOR, TOPSIS and ELECTRE from the MCDM methods. Günay \& Kaya (2017) aimed to compare the financial performances pertaining to 2014-2015 period of the brokerage firms traded in Borsa İstanbul as of 2014 and 2015 using ELECTRE, ORESTE and TOPSIS methods from the MCDM making methods and with the help of eleven financial ratios chosen. As a result of the analyses conducted in 2014 and 2015, similar 
Yönetim ve Ekonomi Araștırmaları Dergisi / Journal of Management and Economics Research

Cilt/Volume: 15 Sayı/Issue: Özel Sayı 1/Special Issue 1 Aralık/December 2017 ss./pp. 155-176 N. Balcı Doi: $\underline{\text { http://dx.doi.org/10.11611/yead.373456 }}$

results were obtained for both years in the study. The analysis has carried out in the study has showed that all the methods employed produce considerable similar results and that they could be used simultaneously.

As for the tourism industry, Yükçü and Atağan (2010) obtained a performance ranking with 4 profitability ratios pertaining to 3 hotels. Ergül (2014) has evaluated the financial performances of 7 companies operating in BIST tourism industry under 11 different criteria using ELECTRE and TOPSIS methods.

Uygurtürk \& Korkmaz (2012) used TOPSIS method to evaluate the financial performance of 13 key metal industry companies traded on the exchange with their 2006-2010 financial statements. In order to determine the performance of Turkish manufacturing industry, Yalçın, Bayrakdaroğlu \& Kahraman (2012) developed an analytical approach which takes financial ratios as the criteria. In this analytical approach, criteria weights were determined with fuzzy AHP method, firms in the industry were sorted using both TOPSIS and VIKOR methods and the results were presented comparatively. While choosing the performance criteria, both account based ratios and value based modern financial performance measurements were utilized. In another study, Bakırc1, Shiraz \& Sattary (2014) carried out financial performance analysis for 14 firms in the traded Iron Steel Metal Key Industry for the years 2009-2011 using the indicators obtained from the firms' financial statements and data envelopment analysis. They used the Data Envelopment Super Activity and TOPSIS methods to rank the firms whose relative activity levels were found according to the data envelopment analysis within themselves. Another recent study carried out by Gümüş et al. (2016) in the metal goods industry have examined 27 firms and have analyzed their 2014-2015 performance using TOPSIS method. As result of the performance analysis has conducted over 11 financial ratios, it was found that no major change occurred in the order by years.

Akyüz \& Kaya (2013) examined the performance of life/pension and non-life insurance companies between 2007 and 2011 using TOPSIS. With ten financial ratios as their criteria. The results of the analysis showed that the most successful year for non-life insurance sector 2007 whereas it was 2008 for life/pension sector. In contrast, the most unsuccessful year for non-life insurance sector occurred as 2008 while life/pension sector had its most unsuccessful year in 2009. In their study, İsseveroğlu \& Sezer (2015) ranked the performances of 16 individual pension companies operating in Turkey between 2008 and 2012 using TOPSIS method. As a result of the analysis, activity levels of the individual pension companies were examined and performance ranking results were revealed. Aytekin \& Karamaşa (2017) analyzed the performances of six insurance companies listed in BIST using financial ratios pertaining to the 2011-2015 period. As a results of the financial applications and the review of the related data; the ratios of currency, cash, debt, net profit margin, return on equity and return on 
Yönetim ve Ekonomi Arastırmaları Dergisi / Journal of Management and Economics Research

Cilt/Volume: 15 Sayı/Issue: Özel Sayı 1/Special Issue 1 Aralık/December 2017 ss./pp. 155-176 N. Balcı Doi: http://dx.doi.org/10.11611/yead.373456

investment were specified as the criteria. To this end, weights of criteria related to financial ratios were obtained using fuzzy Shannon's entropy based on $\alpha$-level set in the first place. Following this, firms' final rankings were determined with fuzzy TOPSIS method.

TOPSIS method, which is used in a variety of sectors as a performance evaluation method as seen above, was used in the present study to evaluate the financial performances of 27 public university hospitals in the years 2014 and 2015. There is a major difference in the ranking of successful and unsuccessful hospitals in general; it was that the ratios used in the analyses deteriorated gradually and the worst performance came out in the year 2015. This study is considered to provide an insight for the health policy decision makers about the conditions of public university hospitals.

\section{METHODOLOGY AND FINDINGS}

\subsection{TOPSIS}

TOPSIS is a useful MDCM technique in dealing with real-world problems (Yoon \& Hwang, 1985). It was first offered by Hwang and Yoon (1981). The technique suggests that the best alternative would be the one that is the nearest to the positive ideal solution and the farthest from the negative ideal solution (Benitez, Martin, and Roman, 2007). The positive ideal solution maximizes the benefit criteria while minimizing the cost criteria, whereas the negative ideal solution is the one that maximizes the cost criteria and minimizes the benefit criteria (Wang \& Elhag, 2006). In conclusion, all the best values in the criteria make up the positive ideal solution whereas the negative ideal solution includes the worst values attainable of criteria (Wang, 2008). In this paper TOPSIS method is used to analyze the performance of public university hospitals.

The steps of the method are described below (Yoon \& Wang 1985; Wang, 2007; Shih, Jhy, \& Stanley, 2007).

Step 1. Decision Matrix: The first step in the application of the method is the determination of a decision matrix. The decision matrix contains the decision points to be ranked in the rows and the evaluation factors to be used in the decision making in the columns. The decision matrix is shown as follows:

$$
D_{i j}=\left[\begin{array}{cccc}
x_{11} & x_{12} & \ldots & x_{1 n} \\
x_{22} & x_{22} & \ldots & x_{2 n} \\
\vdots & \vdots & \vdots & \vdots \\
x_{m 1} & x_{m 2} & \ldots & x_{m n}
\end{array}\right] \quad \mathrm{i}: 1, \ldots, \mathrm{m} \quad \mathrm{j}=1, \ldots, \mathrm{n}
$$

In decision matrix $D_{i j}, \mathrm{~m}$ is the number of decision points, $\mathrm{n}$ is the number of evaluation factors. 
Yönetim ve Ekonomi Araștırmaları Dergisi / Journal of Management and Economics Research Cilt/Volume: 15 Sayı/Issue: Özel Sayı 1/Special Issue 1 Aralık/December 2017 ss./pp. 155-176 N. Balcı Doi: http://dx.doi.org/10.11611/yead.373456

Step 2. Normalized Decision Matrix: In the second step, decision matrix is normalized via equation (2)

$r_{i j}=\frac{x_{i j}}{\sqrt{\sum_{i=1}^{m} x_{i j}^{2}}}$

Normalized decision matrix $\mathrm{R}$ is formed as follows:

$$
R_{i j}=\left[\begin{array}{cccc}
r_{11} & r_{12} & \ldots & r_{1 n} \\
r_{22} & r_{22} & \ldots & r_{2 n} \\
\vdots & \vdots & \vdots & \vdots \\
r_{m 1} & r_{m 2} & \ldots & r_{m n}
\end{array}\right]
$$

Step 3. Weighted Normalized Decision Matrix: The normalization decision matrix is formed by the multiplication of the weight of the evaluation criteria and the respective values of the normalization decision matrix it can be seen below:

$$
\begin{aligned}
& \sum_{j=1}^{n} w_{j}=1 \\
& v_{i j}=w_{i} * r_{i j}=\left[\begin{array}{cccc}
w_{1} r_{11} & w_{2} r_{12} & \ldots & w_{2} r_{1 n} \\
w_{2} r_{22} & w_{2} r_{22} & \ldots & w_{2} r_{2 n} \\
\vdots & \vdots & \vdots & \vdots \\
w_{1} r_{m 1} & w_{2} r_{m 2} & \ldots & w_{2} r_{m n}
\end{array}\right] \quad \mathrm{j}=1,2,3 \ldots \mathrm{J} ; \quad \mathrm{i}: 1,2,3 \ldots . \mathrm{n}
\end{aligned}
$$

$w_{j}=$ Weight of the evaluation criteria which shows importance level

$\mathrm{v}_{\mathrm{ij}}=$ Weighted normalized decision matrix

Step 4. Positive and Negative Ideal Solution: Although positive ideal solution (PIS) is the best performance of the weighted normalized decision matrix, negative ideal solution (NIS) is the worst performance of the weighted normalized decision matrix (Ustasüleyman, 2009). PIS and NIS are determined:

$$
\begin{aligned}
& A^{*}=\left\{\left(\operatorname{maximum}_{i} v_{i j} \mid j \in J\right),\left(\operatorname{minimum}_{i} v_{i j} \mid j \in J^{\prime}\right)\right\} \\
& A^{*}=\left\{v_{1}^{*} ; v_{2}^{*} ; v_{3}^{*} ; \ldots v_{n}^{*}\right\} \\
& A^{-}=\left\{\left(\operatorname{minimum}_{i} v_{i j} \mid j \in J\right),\left(\operatorname{maximum}_{i} v_{i j} \mid j \in J^{\prime}\right)\right\} \\
& A^{-}=\left\{v_{1}^{-} ; v_{2}^{-} ; v_{3}^{-} ; \ldots v_{n}^{-}\right\} \\
& A^{*}=\text { Positive ideal solution } \\
& A^{-}=\text {Negative ideal solution }
\end{aligned}
$$


Yönetim ve Ekonomi Araștırmaları Dergisi / Journal of Management and Economics Research

Cilt/Volume: 15 Sayı/Issue: Özel Sayı 1/Special Issue 1 Aralık/December 2017 ss./pp. 155-176 N. Balcı Doi: http://dx.doi.org/10.11611/yead.373456

Step 5. Distance of Each Alternative from PIS and NIS: TOPSIS is a method based on distance so it determines the best solution is the closest position to PIS and worst solution is the farthest position to NIS. The distances to the positive and negative ideal solution of each alternative are calculated by the Euclidean distance approach (equations 9 and 10), using the values in the weighted normalize decision matrix and the values in the positive and negative ideal solution clusters. (Gümüş, et al., 2016).

$$
\begin{array}{ll}
S_{i}^{*}=\sqrt{\sum_{j=1}^{n}\left(v_{i j}-v_{j}^{*}\right)^{2}} & \mathrm{j}=1,2 \ldots . \mathrm{J} \\
S_{i}^{-}=\sqrt{\sum_{j=1}^{n}\left(v_{i j}-v_{j}^{-}\right)^{2}} & \mathrm{i}=1,2 \ldots . . \mathrm{J}
\end{array}
$$

$S_{i}^{*}=$ Distance of each alternative from PIS

$S_{i}^{-}=$Distance of each alternative from NIS

Step 6. Closeness Coefficient: In the final stage, the closeness coefficient of each alternative is calculated by using equation 11 :

$C_{i}=\frac{S_{i}^{-}}{S_{i}^{-}+S_{i}^{*}} ; 0 \leq C_{i} \leq 1$

$C_{i}=$ The closeness coefficient of each alternative

Then, $C_{i}$ the ranking of alternatives is determined by comparing values (Ertuğrul \& Karakaşoğlu, 2009). The ideal alternative is the one with the highest relative closeness value and should be considered as the best alternative in terms of the related multi-criteria decision making problem.

\subsection{FINANCIAL RATIOS USED IN ANALYSE}

The multi criteria decision making problem defined, aims to evaluate business performances of 27 public university hospitals among all others using their balance sheet and income statement items pertaining to the years 2014 and 2015. Within this scope, financial structure obtain from the financial statements, and 8 different ratios chosen from the activity, profitability and financial structure ratios are included in the evaluation as the performance criteria. The ratios used in the study are presented in Table 1. The first reason for mainly choosing activity and profitability ratios is the fact that TOPSIS method is suitable with the conditions when only "the greatest value is the best one" or "the smallest value is the best one".

Hospitals are organizations that operate for 24 hours treating emergency patients and providing services to inpatients. For this reason, pharmaceuticals and varying types, medical materials and other supplementary materials must be stored adequately in the hospitals so as to interrupt the service flow. For this reason, turnover ratio is included in order to increase the weight of stocks over performance. 
Yönetim ve Ekonomi Araștırmaları Dergisi / Journal of Management and Economics Research Cilt/Volume: 15 Sayı/Issue: Özel Sayı 1/Special Issue 1 Aralık/December 2017 ss./pp. 155-176 N. Balcı Doi: http://dx.doi.org/10.11611/yead.373456

Due to their indebtedness, university hospitals have negative equity. Profitability ratios such as return on equity and activity ratios such as equity turnover are not included in the study because negative equity disturbs to results.

Table 1: Financial Ratios and Explanations

\begin{tabular}{|c|c|c|c|c|}
\hline & Ratio & Name & Explanations & $\begin{array}{l}\text { Ideal } \\
\text { Value }\end{array}$ \\
\hline $\mathrm{R} 1$ & Activity & Receivables Turnover & $\begin{array}{l}\text { Net Sales / Short-Term Trade } \\
\text { Receivables }\end{array}$ & $\max$ \\
\hline $\mathrm{R} 2$ & Activity & Inventory Turnover & COGS / Inventory & $\max$ \\
\hline R3 & Profitability & Net Profit Margin & Net Profit or Loss / Net Sales & $\max$ \\
\hline $\mathrm{R} 4$ & Profitability & Gross Profit Margin & Gross profit/ Net Sales & $\max$ \\
\hline R5 & Profitability & Operating Profit Margin & Operating Profit / Net Sales & $\max$ \\
\hline R6 & Activity & Current Asset Turnover Ratio & Net Sales / Current Assets & $\max$ \\
\hline $\mathrm{R} 7$ & $\begin{array}{l}\text { Financial } \\
\text { Structure }\end{array}$ & $\begin{array}{l}\text { Short-Term Liabilities to } \\
\text { Total Liabilities and Equity }\end{array}$ & $\begin{array}{l}\text { Short-Term Liabilities/(Short-term } \\
\text { Liabilities+ Long-term Liabilities+ } \\
\text { Equity) }\end{array}$ & $\min$ \\
\hline $\mathrm{R} 8$ & Profitability & COGS to Net Sales & COGS / Net Sales & $\min$ \\
\hline
\end{tabular}

\subsection{EMPIRICAL RESULTS}

In the present study, public universities that have hospitals among those listed in the Public Administration Audit Reports of the Court of Accounts are included in evaluations. Since public university hospitals are businesses with revolving funds, the income statements and balance sheets pertaining to the revolving fund business included in the audit reports are considered to reflect the financial situation of the hospitals. In the audit reports, 57 universities have hospitals. Among these 57 hospitals, 27 are included within in the study due to data restrictions in the balance sheets and income statements. The names of the universities used in study and their abbreviations, the ones excluded from the study and the reasons for exclusion are summarized in the Appendix 1-2.

Balance sheet and income statements are obtained from Audit Reports of the Turkish Court of Accounts for the years 2014 and 2015 and then Table 2 is formed. The general financial structure of hospitals can be seen below.

Table 2: Overview of Public University Hospitals Financial Statements

\begin{tabular}{|l|r|r|}
\hline & $\mathbf{2 0 1 4}$ & \multicolumn{1}{|c|}{$\mathbf{2 0 1 5}$} \\
\hline Total Assets & $1,834,639,737.51$ & $1,895,337,744.49$ \\
\hline Total Assets Liabilities & $2,609,094,739.17$ & $3,188,555,094.33$ \\
\hline Equity & $-774,533,887.84$ & $-1,291,350,434.14$ \\
\hline Net Sales & $4,870,669,895.28$ & $5,355,965,996.17$ \\
\hline Net Profit or Loss & $-354,669,522.52$ & $-571,445,969.11$ \\
\hline
\end{tabular}


Yönetim ve Ekonomi Araștırmaları Dergisi / Journal of Management and Economics Research Cilt/Volume: 15 Sayı/Issue: Özel Sayı 1/Special Issue 1 Aralık/December 2017 ss./pp. 155-176 N. Balcı Doi: http://dx.doi.org/10.11611/yead.373456

Table 2 indicates that total liabilities of hospital more than their total assets. Also public university hospitals have had negative equity. Although there has been an increase in net sales, it is seen that the net loss has been increasing gradually between the years 2014 and 2015 .

For TOPSIS analysis, financial ratios were calculated. Later, the decision matrices are established using these ratios exactly, which can be seen below in order by years ${ }^{3}$.

Table 3: Decision Matrix for $2014^{4}$

\begin{tabular}{|c|c|c|c|c|c|c|c|c|}
\hline & R1 & $\mathbf{R 2}$ & R3 & R4 & R5 & R6 & R7 & $\mathbf{R 8}$ \\
\hline $\mathrm{AD}$ & 4.908 & 5.569 & -0.119 & 0.240 & -0.122 & 2.835 & 1.872 & 0.760 \\
\hline AFYN & 5.226 & 9.469 & -0.114 & 0.302 & -0.108 & 3.226 & 1.982 & 0.698 \\
\hline AKNZ & 4.169 & 18.091 & -0.026 & 0.337 & -0.017 & 3.337 & 1.936 & 0.663 \\
\hline ATTRK & 3.146 & 40.347 & -0.006 & 0.362 & -0.024 & 2.031 & 0.203 & 0.638 \\
\hline ÇNNKL & 3.265 & 10.673 & -0.079 & -0.021 & -0.079 & 2.454 & 0.943 & 1.021 \\
\hline DCL & 4.599 & 12.615 & -0.087 & 0.524 & -0.084 & 3.152 & 1.150 & 0.476 \\
\hline DKZ & 6.138 & 12.302 & -0.131 & 0.080 & -0.110 & 3.547 & 2.721 & 0.920 \\
\hline EGE & 6.287 & 5.240 & -0.136 & 0.335 & -0.122 & 3.156 & 1.743 & 0.665 \\
\hline FRT & 4.415 & 8.815 & 0.026 & 0.170 & 0.023 & 2.378 & 0.573 & 0.830 \\
\hline GZ & 3.088 & 5.696 & -0.030 & 0.565 & -0.033 & 2.161 & 1.553 & 0.435 \\
\hline GZNTP & 5.889 & 11.953 & -0.103 & 0.257 & -0.106 & 4.251 & 1.346 & 0.743 \\
\hline HCTTP & 1.530 & 22.017 & -0.229 & -0.117 & -0.182 & 1.380 & 1.476 & 1.117 \\
\hline HRRN & 6.019 & 19.064 & -0.153 & 0.277 & -0.152 & 4.104 & 1.414 & 0.723 \\
\hline INN & 8.392 & 14.890 & -0.011 & 0.310 & -0.013 & 5.600 & 1.510 & 0.690 \\
\hline ISTNBL & 4.235 & 8.380 & -0.010 & 0.115 & -0.032 & 1.859 & 1.254 & 0.885 \\
\hline KMSTC & 3.123 & 5.838 & -0.034 & 0.316 & -0.030 & 2.116 & 0.591 & 0.684 \\
\hline KT & 3.888 & 6.318 & -0.136 & 0.334 & -0.136 & 2.532 & 1.515 & 0.666 \\
\hline KRKL & 5.028 & 10.254 & 0.052 & 0.567 & 0.047 & 3.101 & 1.148 & 0.433 \\
\hline KCL & 13.092 & 10.752 & -0.216 & 0.263 & -0.190 & 6.539 & 3.598 & 0.737 \\
\hline MRSN & 3.760 & 2.740 & -0.110 & 0.380 & -0.114 & 1.861 & 1.686 & 0.620 \\
\hline ONDKZM & 7.913 & 8.580 & -0.027 & 0.322 & -0.049 & 3.704 & 1.190 & 0.678 \\
\hline OSMNGZI & 4.504 & 6.696 & -0.003 & 0.376 & -0.010 & 2.869 & 0.972 & 0.624 \\
\hline PMKKL & 6.483 & 5.709 & 0.018 & 0.374 & 0.060 & 3.658 & 0.982 & 0.626 \\
\hline SCK & 4.682 & 10.166 & -0.069 & 0.290 & -0.065 & 2.698 & 1.470 & 0.710 \\
\hline TRY & 8.233 & 8.280 & -0.192 & 0.273 & -0.188 & 3.938 & 2.861 & 0.727 \\
\hline ULDG & 6.098 & 5.387 & 0.012 & 0.422 & 0.010 & 3.315 & 1.039 & 0.578 \\
\hline YZNCYL & 4.745 & 15.893 & -0.113 & 0.570 & -0.106 & 3.732 & 1.338 & 0.430 \\
\hline Mean & 5.291 & 11.175 & -0.075 & 0.305 & -0.072 & 3.168 & 1.484 & 0.695 \\
\hline Std. Dev. & 2.258 & 7.482 & 0.076 & 0.163 & 0.070 & 1.126 & 0.715 & 0.163 \\
\hline
\end{tabular}

\footnotetext{
${ }^{3}$ The values in Table 3-4 show their own values.

${ }^{4}$ Universities is placed in the decision matrix by shortening their names according to the alphabetical order. The expansions of abbreviations are included in Appendix 2.
} 
Yönetim ve Ekonomi Araștırmaları Dergisi / Journal of Management and Economics Research Cilt/Volume: 15 Sayı/Issue: Özel Sayı 1/Special Issue 1 Aralık/December 2017 ss./pp. 155-176 N. Balcı Doi: http://dx.doi.org/10.11611/yead.373456

Table 4: Decision Matrix for 2015

\begin{tabular}{|c|c|c|c|c|c|c|c|c|}
\hline & R1 & $\mathbf{R 2}$ & R3 & R4 & R5 & R6 & R7 & R8 \\
\hline $\mathrm{AD}$ & 5.661 & 15.097 & -0.260 & 0.133 & -0.261 & 3.741 & 2.993 & 0.867 \\
\hline AFYN & 5.978 & 8.625 & -0.076 & 0.323 & -0.068 & 3.104 & 2.028 & 0.677 \\
\hline AKNZ & 4.007 & 19.924 & -0.181 & 0.227 & -0.194 & 3.131 & 2.553 & 0.773 \\
\hline ATTRK & 4.424 & 28.406 & 0.045 & 0.623 & 0.019 & 1.791 & 0.122 & 0.377 \\
\hline ÇNNKL & 3.434 & 2.832 & -0.006 & 0.143 & -0.015 & 1.452 & 0.893 & 0.857 \\
\hline DCL & 9.241 & 20.994 & 0.072 & 0.486 & 0.067 & 4.771 & 0.825 & 0.514 \\
\hline DKZ & 6.967 & 13.360 & -0.138 & 0.050 & -0.134 & 3.443 & 3.084 & 0.950 \\
\hline EGE & 6.336 & 5.666 & -0.213 & 0.285 & -0.190 & 2.827 & 2.227 & 0.715 \\
\hline FRT & 5.217 & 13.085 & 0.023 & 0.164 & 0.016 & 2.956 & 0.614 & 0.836 \\
\hline $\mathrm{GZ}$ & 2.941 & 6.018 & 0.101 & 0.474 & -0.034 & 2.009 & 1.269 & 0.526 \\
\hline GZNTP & 7.769 & 14.768 & -0.061 & 0.304 & -0.064 & 4.833 & 1.554 & 0.696 \\
\hline HCTTP & 5.784 & 22.183 & -0.304 & -0.115 & -0.212 & 3.905 & 2.216 & 1.115 \\
\hline HRRN & 4.090 & 11.483 & -0.092 & 0.344 & -0.093 & 2.854 & 1.546 & 0.656 \\
\hline INN & 8.171 & 37.223 & -0.170 & 0.161 & -0.173 & 6.056 & 2.595 & 0.839 \\
\hline ISTNBL & 4.045 & 14.468 & -0.165 & -0.011 & -0.167 & 1.752 & 1.533 & 1.011 \\
\hline KMSTC & 3.498 & 7.467 & -0.146 & 0.193 & -0.135 & 2.265 & 0.962 & 0.807 \\
\hline KT & 4.078 & 5.769 & -0.144 & 0.294 & -0.145 & 2.379 & 1.796 & 0.706 \\
\hline KRKL & 5.863 & 11.837 & -0.092 & 0.414 & -0.106 & 3.651 & 2.016 & 0.586 \\
\hline KCL & 16.680 & 44.174 & -0.099 & 0.348 & -0.094 & 8.816 & 4.997 & 0.652 \\
\hline MRSN & 4.570 & 3.019 & -0.202 & 0.329 & -0.129 & 1.977 & 1.972 & 0.671 \\
\hline ONDKZM & 8.651 & 10.540 & -0.103 & 0.254 & -0.107 & 3.668 & 1.486 & 0.746 \\
\hline OSMNGZI & 5.343 & 6.270 & -0.088 & 0.298 & -0.092 & 2.873 & 1.220 & 0.702 \\
\hline PMKKL & 6.739 & 4.864 & -0.006 & 0.310 & 0.003 & 3.064 & 1.002 & 0.690 \\
\hline SCK & 6.496 & 7.012 & -0.197 & 0.131 & -0.172 & 3.552 & 2.857 & 0.869 \\
\hline TRY & 9.522 & 5.252 & -0.181 & 0.387 & -0.107 & 3.556 & 3.268 & 0.613 \\
\hline ULDG & 6.145 & 5.322 & -0.020 & 0.381 & -0.024 & 2.999 & 1.093 & 0.619 \\
\hline YZNCYL & 4.657 & 29.150 & -0.069 & 0.379 & -0.071 & 3.834 & 1.561 & 0.621 \\
\hline Mean & 6.159 & $\mathbf{1 3 . 8 8 2}$ & -0.103 & 0.271 & -0.099 & 3.380 & 1.862 & 0.729 \\
\hline Std. Dev. & 2.759 & 10.607 & 0.100 & 0.159 & 0.079 & 1.493 & 1.018 & 0.159 \\
\hline
\end{tabular}

When profitability ratios ( $\mathrm{R} 3, \mathrm{R} 4, \mathrm{R} 5, \mathrm{R} 8)$ are examined, it could be seen that public university hospitals have to deal with a problem of profitability and make losses. Profitability ratios (R3, R4, R5, R8) were at highest level in 2014 except from COGS / Net Sales (R8). An increase in the COGS to Net Sales (R8) ratio is undesirable because it shows that costs are on a gradual increase.

Short-Term Liabilities to Total Liabilities and Equity ratio (R7) indicates the debt structures of public university hospitals, it is found that the share of short term foreign resources increased gradually among all the resources and the three-year average came out as 1.8, which can be translated as hospitals are in debt for 1.8 times of their assets. In short, it is seen that hospitals are having great difficulty paying their short-term debts. 
Yönetim ve Ekonomi Araștırmaları Dergisi / Journal of Management and Economics Research

Cilt/Volume: 15 Sayı/Issue: Özel Sayı 1/Special Issue 1 Aralık/December 2017 ss./pp. 155-176 N. Balcı Doi: http://dx.doi.org/10.11611/yead.373456

As for the examination of activity ratios (R1-R2-R6), inventory turnover (R2) is seen to increase in years. As institutions operating twenty-four hours, it is necessary for hospitals to always keep sufficient amounts of inventory to avoid any failure in health care services; however, financial difficulties make hospitals reduce their stocks. As one can understand from inventory turnover ratio, hospitals are trying to make inventory turnover as quick as possible. That is, in addition to disposing of the stocks in a shorter time in 2015 than 2014, a faster recovery of receivables is another noticeable finding.

In second step, decision matrix is normalized via Equation 2 and normalized decision matrix is constructed like Equation 3. The normalization decision matrices for the years 2014-2015 are given in Appendix 3- 4. In the third step, each value of normalize decision matrix is weighted with a value such as $w_{j}$. The weighting process should be done according to factor importance. Likewise, financial ratios, the weights given by decisions makers also affect the ranking of the firms. In this study, all factors are weighted equally and weighted normalized decision matrixes can be seen in Appendix 5-6. In forth step we need to determine PIS and NIS for each year and it can be seen below:

For the year 2014

$A^{*}=\{0.055,0.073,0.012,0.040, \quad 0.014,0.047,0.003,0.014\}$

$A^{-}=\{0.007,0.005,-0.052,-0.008,-0.046,0.010,0.053,0.038\}$

For the year 2015

$A^{*}=\{0.060,0.061,0.017,0.048,0.013,0.058,0.001,0.012\}$

$A^{-}=\{0.011,0.004,-0.051,-0.009,-0.050,0.009,0.057,0.036\}$

The distance of each alternative from PIS and NIS are found in step 5 and in step 6 the closeness coefficient of each alternative is calculated as shown in Appendix 7. Final rankings of public university hospitals according to Ci values between years 2014-2015 are seen below in Table 4. In other words, after performance evaluation of the Turkish public university hospitals by taking 8 financial ratios into consideration, the order of the firms was found as in Table 4.

Table 5: Rankings of Public University Hospitals According to Ci Values between Years 2014-2015

\begin{tabular}{|l|c|c|c|c|}
\hline & \multicolumn{2}{|c|}{$\mathbf{2 0 1 4}$} & \multicolumn{2}{c|}{$\mathbf{2 0 1 5}$} \\
\hline & Ci & Rank & Ci & Rank \\
\hline AD & 0.334 & 23 & 0.249 & 27 \\
\hline AFYN & 0.468 & 14 & 0.530 & 7 \\
\hline AKNZ & 0.518 & 7 & 0.310 & 23 \\
\hline ATTRK & 0.648 & 1 & 0.609 & 2 \\
\hline CNNKL & 0.425 & 17 & 0.465 & 11 \\
\hline DCL & 0.472 & 11 & 0.694 & 1 \\
\hline DKZ & 0.309 & 25 & 0.325 & 21 \\
\hline
\end{tabular}


Yönetim ve Ekonomi Araștırmaları Dergisi / Journal of Management and Economics Research Cilt/Volume: 15 Sayı/Issue: Özel Sayı 1/Special Issue 1 Aralık/December 2017 ss./pp. 155-176 N. Balcı Doi: http://dx.doi.org/10.11611/yead.373456

\begin{tabular}{|l|c|c|c|c|}
\hline & \multicolumn{2}{|c|}{$\mathbf{2 0 1 4}$} & \multicolumn{2}{c|}{2015} \\
\hline EGE & 0.346 & 21 & 0.302 & 24 \\
\hline FRT & 0.533 & 6 & 0.535 & 4 \\
\hline GZ & 0.478 & 10 & 0.531 & 6 \\
\hline GZNTP & 0.417 & 18 & 0.515 & 9 \\
\hline HCTTP & 0.276 & 27 & 0.277 & 25 \\
\hline HRRN & 0.395 & 19 & 0.436 & 15 \\
\hline INN & 0.593 & 3 & 0.452 & 12 \\
\hline ISTNBL & 0.453 & 15 & 0.315 & 22 \\
\hline KCL & 0.470 & 12 & 0.368 & 18 \\
\hline KMSTC & 0.326 & 24 & 0.353 & 19 \\
\hline KRKL & 0.604 & 2 & 0.451 & 13 \\
\hline KT & 0.366 & 20 & 0.583 & 3 \\
\hline MRSN & 0.341 & 22 & 0.332 & 20 \\
\hline ONDKZM & 0.512 & 9 & 0.445 & 14 \\
\hline OSMNGZI & 0.515 & 8 & 0.433 & 16 \\
\hline PMKKL & 0.575 & 4 & 0.522 & 8 \\
\hline SCK & 0.430 & 16 & 0.273 & 26 \\
\hline TRY & 0.280 & 26 & 0.378 & 17 \\
\hline ULDG & 0.547 & 5 & 0.512 & 10 \\
\hline YZNCYL & 0.469 & 13 & 0.532 & 5 \\
\hline
\end{tabular}

According to the results in Table 4, the top three hospitals with highest performance in 2014 are; Atatürk University Hospital, Kırıkkale University Hospital, İnönü University Hospital respectively. In 2015, three best performance belongs to Dicle University Hospital, Atatürk University Hospital, Karadeniz Teknik University Hospital. In 2014, hospitals with the lowest performance are Dokuz Eylül University Hospital, Trakya University Hospital, Hacettepe University Hospital. In 2015 hospitals with lowest performance are Hacettepe University Hospital, Selçuk University Hospital, Adnan Menderes University Hospital.

It is found that Atatürk University Hospitals is ranked as the best three performance and Hacettepe University Hospital is ranked as the worst three performance for these 2 years. In general, it has been determined that there are very large changes in the ranking.

\section{CONCLUSION AND DISCUSSION}

Health care reforms have been gaining importance in Turkey like all around the world and governments are putting intensive effort to improve their health care systems and meet the requirements of their citizens. These reforms, attempted with the conscious to have healthy generations, bring about increased costs as well. Many countries are questioning the sustainability of their health care systems. 
Yönetim ve Ekonomi Araștırmaları Dergisi / Journal of Management and Economics Research

Cilt/Volume: 15 Sayı/Issue: Özel Sayı 1/Special Issue 1 Aralık/December 2017 ss./pp. 155-176

N. Balcı Doi: http://dx.doi.org/10.11611/yead.373456

Similarly in Turkey, health reforms that have been made since 2003 have caused increases in health expenditures and one of the mostly affected institutions by these reform changes have been public university hospitals. Public university hospitals are facing heavy cost restrictions under the current economic conditions and they are struggling to survive. As a very critical part of the health care system, university hospitals have a major role in raising healthy generations in a country since they provide medical education, train academicians, serve as research centers and offer continuous health care services. Therefore, health policy makers have to follow the performance of university hospitals with utmost care.

The best way to observe financial performance is to follow the financial ratios obtained from financial statements regularly. In the present study, 27 public universities having hospitals are included in analyses and their 2-year performance analyses based on the years 2014-2015 are carried out using TOPSIS method. The method is applied to 8 financial ratios and the hospitals are ranked by performance in the given years.

There are some of limitations to the analysis. Firstly, financial tables of public university hospitals could not be reach directly in this study. As the public university hospitals are the organizations with revolving funds, the financial tables of the revolving fund administration are considered to reflect the financial status of the hospitals. The second limitation of study is that the fixed assets of university hospitals are not included in their financial tables. They are shown in the main financial statements of the university. For this reason, financial ratios including total assets or fixed assets cannot be included in the study. Thirdly, public university hospitals have negative equity, which makes it difficult to interpret the results.

According to the findings obtained, the hospital with the highest performance changes every year and significant differences are observed in the performance orders. It is remarkable that the performances of hospitals changed this much throughout years. For instance, Dicle University Hospital has the $13^{\text {th }}$ best performance in ranking in 2014. It has best performance in 2015.

There is a dramatic changes in the performances of hospitals in following year. One of the reasons of these changes university public hospitals affected by Health Transformation Program since 2003, their financial positions has been deteriorating and Ministry of Health was transferred 55 million TL transferred to hospital as applied training support. Moreover, within the scope of the reimbursement system called Global Budget applied by the Ministry of Health to public hospitals, a similar protocol was signed with Hacettepe, Dicle and Ankara universities in 2015. With this protocol ${ }^{5}$, the cost of health services they produced was calculated on the Medula system and a total revenue of 764 million TL was

\footnotetext{
${ }^{5}$ MEDULA system refers to integrated system that helps to collect electronical bills at perform reimbursement.
} 
Yönetim ve Ekonomi Araștırmaları Dergisi / Journal of Management and Economics Research

Cilt/Volume: 15 Sayı/Issue: Özel Sayı 1/Special Issue 1 Aralık/December 2017 ss./pp. 155-176 N. Balcı Doi: http://dx.doi.org/10.11611/yead.373456

allocated to these three universities in 2015. After this revenue increase, Dicle University hospital had the best performance ranking in 2015. Hacettepe University hospital ranking only has increased 2 rang and has 25 th performance ranking. It is noteworthy that the changes in the performance of the two universities signed by the protocol are not in the same level.

The analysis and findings are considered to be beneficial for health policy decision makers in analysing the conditions of public university hospitals. It is believed that the dramatic changes occurring in the performances of hospitals year by year must be studied as well. It is also considered that determining the characteristics of hospitals with the best and worst performances in further studies would be beneficial in making health care policies.

\section{REFERENCES}

Akgün, M., \& Soy Temür, A. (2016) "BIST Ulaştırma Endeksine Kayıtlı Şirketlerin Finansal Performanslarının TOPSIS Yöntemi ile Değerlendirilmesi”, Uluslararası Yönetim İktisat ve İşletme Dergisi, 30, 173-186.

Akkaya, G. C. (2004) "Finansal Rasyolar Yardımıyla Havayolları İşletmelerinin Performansının Değerlendirilmesi”, Dokuz Eylül Üniversitesi İktisadi ve İdari Bilimler Fakültesi Dergisi, 19(1).

Akyüz, Y., \& Kaya, Z. (2013) “Türkiye'de Hayat Dış1 ve HayatlEmeklilik Sigorta Sektörünün Finansal Performans Analiz ve Değerlendirilmesi”, Sosyal Ekonomik Araştırmalar Dergisi, (26), 355 371.

Aytekin, A., \& Karamaşa, Ç. (2017) “Analyzing Financial Performance of Insurance Companies Traded in BIST via Fuzzy Shannon's Entropy Based Fuzzy TOPSIS Methodology”, The Journal of Operations Research, Statistics, Econometrics and Management Information Systems, Volume 5, Issue 1, 2017.

Bakirci, F., Shiraz, S. E., \& Sattary, A. (2014) "BIST'da Demir, Çelik Metal Ana Sanayi Sektöründe Faaliyet Gösteren İşletmelerin Finansal Performans Analizi: VZA Süper Etkinlik ve TOPSIS Uygulamas1/Financial Performance Analysis of Iron, Steel Metal Industry Sector Companies in The Borsa İstanbul: DEA Super Efficiency and TOPSIS Methods", Ege Akademik Bakış, 14(1), 9.

Benitez, J. M., Martín, J. C., \& Román, C. (2007) “Using Fuzzy Number for Measuring Quality of Service in the Hotel Industry", Tourism Management, 28(2), 544-555. 
Yönetim ve Ekonomi Araștırmaları Dergisi / Journal of Management and Economics Research

Cilt/Volume: 15 Sayı/Issue: Özel Sayı 1/Special Issue 1 Aralık/December 2017 ss./pp. 155-176

N. Balcı Doi: http://dx.doi.org/10.11611/yead.373456

Demireli, E. (2010) “TOPSIS Çok Kriterli Karar Verme Sistemi: Türkiye’deki Kamu Bankaları Üzerine Bir Uygulama”, Girişimcilik ve Kalkınma Dergisi (5:1), 101-112.

Ege, İ., Topaloğlu, E. E., \& Özyamanoğlu, M. (2013) "Finansal Performans ile Kurumsal Yönetim Notları Arasındaki İlişki: BIST Üzerine Bir Uygulama”, Akademik Araştırmalar ve Çalışmalar Dergisi (AKAD), 5(9).

Eleren, A., \& Karagül, M. (2008) “1986-2006 Türkiye Ekonomisinin Performans Değerlendirmesi”, Yönetim ve Ekonomi: Celal Bayar Üniversitesi İktisadi ve İdari Bilimler Fakültesi Dergisi, $15(1), 1-14$.

Ergül, N. (2014). BİST-Turizm Sektöründeki Şirketlerin Finansal Performans Analizi. Çankırı Karatekin Üniversitesi İktisadi ve İdari Bilimler Fakültesi Dergisi, 4(1), 325-340.

Gülşen, M. A., \& Yıldıran, M. (2017) "Mali Regülasyon Olarak Sağlık Regülasyonlarının Sağlık Kurumlarına Etkisi: Türkiye'de Üniversite Hastaneleri ve Sağlık Uygulama Tebliği”, AİBÜİ̈BF Ekonomik ve Sosyal Araştırmalar Dergisi.

Gümüs, Y., Özdagoglu, A., Gümüs, G. K., \& Özdagoglu, G. (2016), “Bilanço ve Gelir Tablolarının TOPSIS Yöntemi ile Analizi-i: Borsa İstanbul Uygulamas1/The Analysıs of Balance Sheet And Income Statement With TOPSIS: An Application on Bora Istanbul”, Muhasebe ve Denetime Bakış, Accounting \& Auditing Review, 16(50), 79.

Günay, B., \& Kaya, İ, (2017) "Borsa İstanbul'da Yer Alan Aracı Kurumların Performansının Çok Kriterli Karar Verme Yöntemleri ile Değerlendirilmesi”, Manisa Celal Bayar Üniversitesi Sosyal Bilimler Dergisi, Cilt 15, Say1 2.

İşseveroğlu, G., \& Sezer, O, (2015) “Financial Performance of Pension Companies Operating in Turkey with TOPSIS Analysis Method", International Journal of Academic Research in Accounting, Finance and Management Sciences, 5(1), 137-147.

Ömürbek, V., \& Kınay, Ö. G. B. (2013) “Havayolu Taşımacılığı Sektöründe TOPSIS Yöntemiyle Finansal Performans Değerlendirmesi”, Süleyman Demirel Üniversitesi İktisadi ve İdari Bilimler Fakültesi Dergisi, 18(3).

Öztürk, S., \& Uçan, O. (2017) “Türkiye'de Sağlık Harcamalarında Artış Nedenleri: Sağlık Harcamalarında Artış-Büyüme İlişkisi”, Süleyman Demirel Üniversitesi İktisadi ve İdari Bilimler Fakültesi Dergisi, C.22, S.1, s.139-152.

Shih, H. S., Shyur, H. J., \& Lee, E. S. (2007). "An Extension of TOPSIS for Group Decision Making”, Mathematical and Computer Modelling, 45(7), 801-813. 
Yönetim ve Ekonomi Araștırmaları Dergisi / Journal of Management and Economics Research Cilt/Volume: 15 Sayı/Issue: Özel Sayı 1/Special Issue 1 Aralık/December 2017 ss./pp. 155-176 N. Balcı Doi: http://dx.doi.org/10.11611/yead.373456

Taşabat, S. E., Cinemre, N., \& Şen, S. (2015), “Farklı Ağırlıklandırma Tekniklerinin Denendiği Çok Kriterli Karar Verme Yöntemleri ile Türkiye'deki Mevduat Bankalarının Mali Performanslarının Değerlendirilmesi”, Sosyal Bilimler Araştırma Dergisi, 4(2), 96-110.

Türkmen, F. (2016) “Üniversite Hastanelerinin Yeniden Yapılandırılması, Üniversite Hastaneleri Birliği Derneği 18. Toplantısı", Osmangazi Üniversitesi, 26-27 Şubat 2017, Erişim: http://www.uhbd.org/Genel\%20Toplant\%C4\%B1lar/universite-hastaneleri-birligi-dernegi-18toplantisi- osmangazi-universitesi-, Erişim tarihi 11.04.2016.

Ustasüleyman, T. (2009) “Bankacılık Sektöründe Hizmet Kalitesinin Değerlendirilmesi: AHS-TOPSIS Yöntemi”, Bankacılar Dergisi, 69, 33-43.

Uygurtürk, H., \& Korkmaz, T. (2012) "Finansal Performansın TOPSIS Çok Kriterli Karar Verme Yöntemi ile Belirlenmesi: Ana Metal Sanayi İşletmeleri Üzerine Bir Uygulama”, Eskişehir.

Wang, Y. M., \& Elhag, T. M. (2006) "Fuzzy TOPSIS Method Based on Alpha Level Sets with an Application to Bridge Risk Assessment”. Expert systems with applications, 31(2), 309-319.

Wang, Y. J. (2008) “Applying FMCDM to Evaluate Financial Performance of Domestic Airlines in Taiwan”, Expert Systems with Applications, 34(3), 1837-1845.

Yalçın, N., Bayrakdaroglu, A., \& Kahraman, C. (2012) "Application of Fuzzy Multi-Criteria Decision Making Methods for Financial Performance Evaluation of Turkish Manufacturing Industries", Expert Systems with Applications, 39(1), 350-364.

Yayar, R., \& Baykara, H. V. (2012). “TOPSIS Yöntemi ile Katilim Bankalarının Etkinliği ve Verimliliği Üzerine Bir Uygulama/An Implementation upon Efficiency and Productivity of Participation Banks with TOPSIS Method”, Business and Economics Research Journal, 3(4), 21.

Yeh, C. H. (2002) “A Problem-based Selection of Multi-attribute Decision-making Methods", International Transactions in Operational Research, 9(2), 169-181.

Yiğit, V., \& Yiğit, A. (2016) "Üniversite Hastanelerinin Finansal Sürdürülebilirliği-Financial Sustainability of University Hospitals", Mehmet Akif Ersoy Üniversitesi Sosyal Bilimler Enstitüsü Dergisi, 8(16), 253-273.

Yoon, K., \& Hwang, C. L. (1985) "Manufacturing plant location analysis by multiple attribute decision making: Part I—single-plant strategy", International Journal of Production Research, 23(2), 345-359.

Yükçü, S., \& Atağan, G. (2010), “TOPSIS Yöntemine Göre Performans Değerleme”, Muhasebe ve Finansman Dergisi, (45). 
Yönetim ve Ekonomi Arastırmaları Dergisi / Journal of Management and Economics Research

Cilt/Volume: 15 Sayı/Issue: Özel Sayı 1/Special Issue 1 Aralık/December 2017 ss./pp. 155-176

N. Balcı Doi: http://dx.doi.org/10.11611/yead.373456

\section{APPENDIX}

Appendix-1: Universities not Included in the Study

\begin{tabular}{|c|c|}
\hline University Name & Reason \\
\hline Abant İzzet Baysal & $\begin{array}{l}\text { Hospital affiliated with the Public Hospitals } \\
\text { Association in } 2014\end{array}$ \\
\hline $\begin{array}{l}\text { Adıyaman, Ankara, Bozok, Bülent Ecevit, Celal Bayar, } \\
\text { Çukurova, Düzce, Erciyes, Erzincan, Hitit, İstanbul } \\
\text { Medeniyet, Marmara, Mehmet Akif Ersoy, Mustafa } \\
\text { Kemal, Namık Kemal, Necmettin Erbakan, Ordu, Recep } \\
\text { Tayip Erdoğan, Süleyman Demirel }\end{array}$ & There is missing data problem for balance sheets \\
\hline Ahi Evran & $\begin{array}{l}\text { Hospital affiliated with the Public Hospitals } \\
\text { Association in } 2011\end{array}$ \\
\hline Anadolu & $\begin{array}{l}\text { University is not included to the sample because its } \\
\text { revolving fund's financial statements include the } \\
\text { income and expenses of the Distant Training } \\
\text { Program that program generates higher revenue } \\
\text { than other units, and distorts the analysis results. }\end{array}$ \\
\hline Balıkesir, Dumlupınar, Giresun, Kafkas & Hospitals do not have inventories \\
\hline Cumhuriyet, & $\begin{array}{l}\text { Financial Director is be assigned by Ministry of } \\
\text { Health }\end{array}$ \\
\hline Muğla Sıtkı Çoban, Sakarya & $\begin{array}{l}\text { University have been taken over by the Ministry of } \\
\text { Health since } 2011\end{array}$ \\
\hline
\end{tabular}

Appendix-2: Abbreviations of Public University Hospitals

\begin{tabular}{|l|l|l|l|}
\hline \multicolumn{1}{|c|}{ University Hospitals } & \multicolumn{1}{c|}{ Abb. } & \multicolumn{1}{c|}{ University Hospitals } & \multicolumn{1}{c|}{ Abb. } \\
\hline Adnan Menderes University & AD & İnönü University Hospital & INN \\
\hline Afyon University Hospital & AFYN & İstanbul University Hospital & ISTNBL \\
\hline Akdeniz University Hospital & AKNZ & Karadeniz Teknik University Hospital & KT \\
\hline Atatürk University Hospital & ATTRK & $\begin{array}{l}\text { Kahramanmaraş Sütçü İmam University } \\
\text { Hospital }\end{array}$ & KMSTC \\
\hline Cumhuriyet University Hospital & CHRYT & Kırıkkale University Hospital & KRKL \\
\hline $\begin{array}{l}\text { Çanakkale Onsekiz Mart University } \\
\text { Hospital }\end{array}$ & ÇNKKL & Kocaeli University Hospital & KCL \\
\hline Dicle University Hospital & DCL & Mersin University Hospital & MRSN \\
\hline Dokuz Eylül University Hospital & DKZ & On Dokuz Mayis University Hospital & ONDKZM \\
\hline Ege University Hospital & EGE & Eskişehir Osmangazi University Hospital & EOSMNGZ \\
\hline Firat University Hospital & FRT & Pamukkale University Hospital & PMKKL \\
\hline Gazi University Hospital & GZ & Selçuk University Hospital & SCK \\
\hline Gaziantep University Hospital & GZNTP & Trakya University Hospital & TRY \\
\hline Hacettepe University Hospital & HCTTP & Uludağ University Hospital & ULDG \\
\hline Harran University Hospital & HRRN & Yüzüncü Yıl University Hospital & YZNCYL \\
\hline
\end{tabular}

Appendix-3: Normalized Decision Matrix for 2014 
Yönetim ve Ekonomi Araștırmaları Dergisi / Journal of Management and Economics Research Cilt/Volume: 15 Sayı/Issue: Özel Sayı 1/Special Issue 1 Aralık/December 2017 ss./pp. 155-176 N. Balcı Doi: http://dx.doi.org/10.11611/yead.373456

\begin{tabular}{|c|c|c|c|c|c|c|c|c|}
\hline & R1 & R2 & R3 & R4 & $\mathrm{R5}$ & R6 & R7 & R8 \\
\hline $\mathrm{AD}$ & 0.164 & 0.080 & -0.216 & 0.134 & -0.236 & 0.163 & 0.219 & 0.205 \\
\hline AFYN & 0.175 & 0.136 & -0.208 & 0.169 & -0.209 & 0.185 & 0.232 & 0.188 \\
\hline AKNZ & 0.140 & 0.260 & -0.048 & 0.189 & -0.033 & 0.191 & 0.227 & 0.179 \\
\hline ATTRK & 0.105 & 0.581 & -0.011 & 0.203 & -0.047 & 0.117 & 0.024 & 0.172 \\
\hline ÇNNKL & 0.109 & 0.154 & -0.143 & -0.012 & -0.153 & 0.141 & 0.111 & 0.275 \\
\hline DCL & 0.154 & 0.182 & -0.159 & 0.293 & -0.164 & 0.181 & 0.135 & 0.128 \\
\hline DKZ & 0.206 & 0.177 & -0.238 & 0.045 & -0.214 & 0.203 & 0.319 & 0.248 \\
\hline EGE & 0.211 & 0.075 & -0.247 & 0.187 & -0.237 & 0.181 & 0.204 & 0.179 \\
\hline FRT & 0.148 & 0.127 & 0.047 & 0.095 & 0.044 & 0.136 & 0.067 & 0.224 \\
\hline GZ & 0.103 & 0.082 & -0.054 & 0.316 & -0.064 & 0.124 & 0.182 & 0.117 \\
\hline GZNTP & 0.197 & 0.172 & -0.187 & 0.144 & -0.206 & 0.244 & 0.158 & 0.200 \\
\hline НCTTP & 0.053 & 0.317 & -0.417 & -0.066 & -0.352 & 0.079 & 0.173 & 0.301 \\
\hline HRRN & 0.202 & 0.274 & -0.278 & 0.155 & -0.296 & 0.235 & 0.166 & 0.195 \\
\hline INN & 0.281 & 0.214 & -0.020 & 0.174 & -0.024 & 0.321 & 0.177 & 0.186 \\
\hline ISTNBL & 0.142 & 0.121 & -0.019 & 0.064 & -0.062 & 0.107 & 0.147 & 0.239 \\
\hline KMSTC & 0.105 & 0.084 & -0.061 & 0.177 & -0.059 & 0.121 & 0.069 & 0.185 \\
\hline KT & 0.130 & 0.091 & -0.247 & 0.187 & -0.265 & 0.145 & 0.178 & 0.180 \\
\hline KRKL & 0.168 & 0.148 & 0.094 & 0.318 & 0.091 & 0.178 & 0.135 & 0.117 \\
\hline KCL & 0.438 & 0.155 & -0.394 & 0.147 & -0.368 & 0.375 & 0.422 & 0.199 \\
\hline MRSN & 0.126 & 0.039 & -0.200 & 0.212 & -0.220 & 0.107 & 0.198 & 0.167 \\
\hline ONDKZM & 0.265 & 0.123 & -0.049 & 0.180 & -0.096 & 0.212 & 0.140 & 0.183 \\
\hline OSMNGZI & 0.151 & 0.096 & -0.006 & 0.210 & -0.020 & 0.165 & 0.114 & 0.168 \\
\hline PMKKL & 0.224 & 0.082 & 0.033 & 0.209 & 0.116 & 0.210 & 0.115 & 0.169 \\
\hline SCK & 0.157 & 0.146 & -0.126 & 0.162 & -0.126 & 0.155 & 0.172 & 0.191 \\
\hline TRY & 0.276 & 0.119 & -0.348 & 0.153 & -0.365 & 0.226 & 0.335 & 0.196 \\
\hline ULDG & 0.204 & 0.078 & 0.022 & 0.236 & 0.020 & 0.190 & 0.122 & 0.156 \\
\hline YZNCYL & 0.159 & 0.229 & -0.205 & 0.319 & -0.206 & 0.214 & 0.157 & 0.116 \\
\hline
\end{tabular}

Appendix 4: Normalized Decision Matrix for 2015

\begin{tabular}{|l|r|r|r|r|r|r|r|r|}
\hline & \multicolumn{1}{|c|}{ R1 } & \multicolumn{1}{c|}{ R2 } & \multicolumn{1}{c|}{ R3 } & \multicolumn{1}{c|}{ R4 } & \multicolumn{1}{c|}{ R5 } & \multicolumn{1}{c|}{ R6 } & \multicolumn{1}{c|}{ R7 } & \multicolumn{1}{c|}{ R8 } \\
\hline AD & 0.162 & 0.167 & -0.352 & 0.082 & -0.399 & 0.195 & 0.273 & 0.224 \\
\hline AFYN & 0.171 & 0.096 & -0.103 & 0.199 & -0.104 & 0.162 & 0.185 & 0.175 \\
\hline AKNZ & 0.115 & 0.221 & -0.245 & 0.140 & -0.296 & 0.164 & 0.232 & 0.199 \\
\hline ATTRK & 0.127 & 0.315 & 0.060 & 0.384 & 0.029 & 0.094 & 0.011 & 0.097 \\
\hline ÇNNKL & 0.098 & 0.031 & -0.008 & 0.088 & -0.023 & 0.076 & 0.081 & 0.221 \\
\hline DCL & 0.264 & 0.233 & 0.098 & 0.299 & 0.102 & 0.249 & 0.075 & 0.133 \\
\hline DKZ & 0.199 & 0.148 & -0.186 & 0.031 & -0.204 & 0.180 & 0.281 & 0.245 \\
\hline EGE & 0.181 & 0.063 & -0.289 & 0.175 & -0.290 & 0.148 & 0.203 & 0.185 \\
\hline FRT & 0.149 & 0.145 & 0.031 & 0.101 & 0.025 & 0.154 & 0.056 & 0.216 \\
\hline GZ & 0.084 & 0.067 & 0.137 & 0.292 & -0.052 & 0.105 & 0.116 & 0.136 \\
\hline GZNTP & 0.222 & 0.164 & -0.083 & 0.188 & -0.098 & 0.252 & 0.142 & 0.179 \\
\hline HCTTP & 0.165 & 0.246 & -0.412 & -0.071 & -0.324 & 0.204 & 0.202 & 0.288 \\
\hline HRRN & 0.117 & 0.127 & -0.125 & 0.212 & -0.142 & 0.149 & 0.141 & 0.169 \\
\hline INN & 0.234 & 0.413 & -0.230 & 0.099 & -0.265 & 0.316 & 0.236 & 0.216 \\
\hline ISTNBL & 0.116 & 0.160 & -0.223 & -0.007 & -0.255 & 0.092 & 0.140 & 0.261 \\
\hline KMSTC & 0.100 & 0.083 & -0.197 & 0.119 & -0.206 & 0.118 & 0.088 & 0.208 \\
\hline KT & 0.117 & 0.064 & -0.195 & 0.181 & -0.222 & 0.124 & 0.164 & 0.182 \\
\hline KRKL & 0.168 & 0.131 & -0.124 & 0.256 & -0.161 & 0.191 & 0.184 & 0.151 \\
\hline
\end{tabular}


Yönetim ve Ekonomi Araștırmaları Dergisi / Journal of Management and Economics Research Cilt/Volume: 15 Sayı/Issue: Özel Sayı 1/Special Issue 1 Aralık/December 2017 ss./pp. 155-176 N. Balcı Doi: http://dx.doi.org/10.11611/yead.373456

\begin{tabular}{|l|c|c|c|r|r|r|r|r|}
\hline & \multicolumn{1}{|c|}{ R1 } & \multicolumn{1}{c|}{ R2 } & \multicolumn{1}{c|}{ R3 } & \multicolumn{1}{c|}{ R4 } & \multicolumn{1}{c|}{ R5 } & \multicolumn{1}{c|}{ R6 } & \multicolumn{1}{c|}{ R7 } & R8 \\
\hline KCL & 0.477 & 0.490 & -0.134 & 0.214 & -0.144 & 0.461 & 0.455 & 0.168 \\
\hline MRSN & 0.131 & 0.033 & -0.273 & 0.203 & -0.196 & 0.103 & 0.180 & 0.173 \\
\hline ONDKZM & 0.247 & 0.117 & -0.139 & 0.156 & -0.163 & 0.192 & 0.135 & 0.193 \\
\hline OSMNGZI & 0.153 & 0.070 & -0.120 & 0.184 & -0.141 & 0.150 & 0.111 & 0.181 \\
\hline PMKKL & 0.193 & 0.054 & -0.007 & 0.191 & 0.004 & 0.160 & 0.091 & 0.178 \\
\hline SCK & 0.186 & 0.078 & -0.267 & 0.081 & -0.263 & 0.186 & 0.260 & 0.224 \\
\hline TRY & 0.272 & 0.058 & -0.245 & 0.239 & -0.163 & 0.186 & 0.298 & 0.158 \\
\hline ULDG & 0.176 & 0.059 & -0.027 & 0.235 & -0.036 & 0.157 & 0.100 & 0.160 \\
\hline YZNCYL & 0.133 & 0.323 & -0.093 & 0.233 & -0.108 & 0.200 & 0.142 & 0.160 \\
\hline
\end{tabular}

Appendix-5: Weighted Normalized Decision Matrix for 2014

\begin{tabular}{|l|c|r|r|r|r|r|r|r|}
\hline & R1 & \multicolumn{1}{c|}{ R2 } & \multicolumn{1}{c|}{ R3 } & \multicolumn{1}{c|}{ R4 } & \multicolumn{1}{c|}{ R5 } & \multicolumn{1}{c|}{ R6 } & \multicolumn{1}{c|}{ R7 } & R8 \\
\hline AD & 0.021 & 0.010 & -0.027 & 0.017 & -0.030 & 0.020 & 0.027 & 0.026 \\
\hline AFYN & 0.022 & 0.017 & -0.026 & 0.021 & -0.026 & 0.023 & 0.029 & 0.024 \\
\hline AKNZ & 0.017 & 0.033 & -0.006 & 0.024 & -0.004 & 0.024 & 0.028 & 0.022 \\
\hline ATTRK & 0.013 & 0.073 & -0.001 & 0.025 & -0.006 & 0.015 & 0.003 & 0.022 \\
\hline ÇNNKL & 0.014 & 0.019 & -0.018 & -0.001 & -0.019 & 0.018 & 0.014 & 0.034 \\
\hline DCL & 0.019 & 0.023 & -0.020 & 0.037 & -0.020 & 0.023 & 0.017 & 0.016 \\
\hline DKZ & 0.026 & 0.022 & -0.030 & 0.006 & -0.027 & 0.025 & 0.040 & 0.031 \\
\hline EGE & 0.026 & 0.009 & -0.031 & 0.023 & -0.030 & 0.023 & 0.026 & 0.022 \\
\hline FRT & 0.018 & 0.016 & 0.006 & 0.012 & 0.006 & 0.017 & 0.008 & 0.028 \\
\hline GZ & 0.013 & 0.010 & -0.007 & 0.040 & -0.008 & 0.015 & 0.023 & 0.015 \\
\hline GZNTP & 0.025 & 0.022 & -0.023 & 0.018 & -0.026 & 0.030 & 0.020 & 0.025 \\
\hline HCTTP & 0.007 & 0.040 & -0.052 & -0.008 & -0.044 & 0.010 & 0.022 & 0.038 \\
\hline HRRN & 0.025 & 0.034 & -0.035 & 0.019 & -0.037 & 0.029 & 0.021 & 0.024 \\
\hline INN & 0.035 & 0.027 & -0.002 & 0.022 & -0.003 & 0.040 & 0.022 & 0.023 \\
\hline ISTNBL & 0.018 & 0.015 & -0.002 & 0.008 & -0.008 & 0.013 & 0.018 & 0.030 \\
\hline KMSTC & 0.013 & 0.011 & -0.008 & 0.022 & -0.007 & 0.015 & 0.009 & 0.023 \\
\hline KT & 0.016 & 0.011 & -0.031 & 0.023 & -0.033 & 0.018 & 0.022 & 0.022 \\
\hline KRKL & 0.021 & 0.018 & 0.012 & 0.040 & 0.011 & 0.022 & 0.017 & 0.015 \\
\hline KCL & 0.055 & 0.019 & -0.049 & 0.018 & -0.046 & 0.047 & 0.053 & 0.025 \\
\hline MRSN & 0.016 & 0.005 & -0.025 & 0.027 & -0.028 & 0.013 & 0.025 & 0.021 \\
\hline ONDKZM & 0.033 & 0.015 & -0.006 & 0.023 & -0.012 & 0.027 & 0.017 & 0.023 \\
\hline OSMNGZI & 0.019 & 0.012 & -0.001 & 0.026 & -0.002 & 0.021 & 0.014 & 0.021 \\
\hline PMKKL & 0.028 & 0.010 & 0.004 & 0.026 & 0.014 & 0.026 & 0.014 & 0.021 \\
\hline SCK & 0.020 & 0.018 & -0.016 & 0.020 & -0.016 & 0.019 & 0.022 & 0.024 \\
\hline TRY & 0.034 & 0.015 & -0.044 & 0.019 & -0.046 & 0.028 & 0.042 & 0.025 \\
\hline ULDG & 0.026 & 0.010 & 0.003 & 0.029 & 0.002 & 0.024 & 0.015 & 0.019 \\
\hline YZNCYL & 0.020 & 0.029 & -0.026 & 0.040 & -0.026 & 0.027 & 0.020 & 0.014 \\
\hline
\end{tabular}

Appendix-6: Weighted Normalized Decision Matrix for 2015

\begin{tabular}{|l|r|r|r|r|r|r|r|r|}
\hline & \multicolumn{1}{|c|}{ R1 } & \multicolumn{1}{c|}{ R2 } & R3 & \multicolumn{1}{c|}{ R4 } & \multicolumn{1}{c|}{ R5 } & \multicolumn{1}{c|}{ R6 } & \multicolumn{1}{c|}{ R7 } & \multicolumn{1}{c|}{ R8 } \\
\hline AD & 0.020 & 0.021 & -0.044 & 0.010 & -0.050 & 0.024 & 0.034 & 0.028 \\
\hline AFYN & 0.021 & 0.012 & -0.013 & 0.025 & -0.013 & 0.020 & 0.023 & 0.022 \\
\hline AKNZ & 0.014 & 0.028 & -0.031 & 0.018 & -0.037 & 0.020 & 0.029 & 0.025 \\
\hline ATTRK & 0.016 & 0.039 & 0.008 & 0.048 & 0.004 & 0.012 & 0.001 & 0.012 \\
\hline ÇNNKL & 0.012 & 0.004 & -0.001 & 0.011 & -0.003 & 0.009 & 0.010 & 0.028 \\
\hline
\end{tabular}


Yönetim ve Ekonomi Araștırmaları Dergisi / Journal of Management and Economics Research Cilt/Volume: 15 Sayı/Issue: Özel Sayı 1/Special Issue 1 Aralık/December 2017 ss./pp. 155-176 N. Balcı Doi: http://dx.doi.org/10.11611/yead.373456

\begin{tabular}{|c|c|c|c|c|c|c|c|c|}
\hline & R1 & R2 & $\mathbf{R 3}$ & R4 & R5 & R6 & R7 & R8 \\
\hline DCL & 0.033 & 0.029 & 0.012 & 0.037 & 0.013 & 0.031 & 0.009 & 0.017 \\
\hline DKZ & 0.025 & 0.019 & -0.023 & 0.004 & -0.026 & 0.022 & 0.035 & 0.031 \\
\hline EGE & 0.023 & 0.008 & -0.036 & 0.022 & -0.036 & 0.018 & 0.025 & 0.023 \\
\hline FRT & 0.019 & 0.018 & 0.004 & 0.013 & 0.003 & 0.019 & 0.007 & 0.027 \\
\hline GZ & 0.011 & 0.008 & 0.017 & 0.037 & -0.007 & 0.013 & 0.014 & 0.017 \\
\hline GZNTP & 0.028 & 0.020 & -0.010 & 0.023 & -0.012 & 0.032 & 0.018 & 0.022 \\
\hline НСТTP & 0.021 & 0.031 & -0.051 & -0.009 & -0.040 & 0.026 & 0.025 & 0.036 \\
\hline HRRN & 0.015 & 0.016 & -0.016 & 0.027 & -0.018 & 0.019 & 0.018 & 0.021 \\
\hline INN & 0.029 & 0.052 & -0.029 & 0.012 & -0.033 & 0.040 & 0.030 & 0.027 \\
\hline ISTNBL & 0.014 & 0.020 & -0.028 & -0.001 & -0.032 & 0.011 & 0.017 & 0.033 \\
\hline KMSTC & 0.013 & 0.010 & -0.025 & 0.015 & -0.026 & 0.015 & 0.011 & 0.026 \\
\hline KT & 0.015 & 0.008 & -0.024 & 0.023 & -0.028 & 0.016 & 0.020 & 0.023 \\
\hline KRKL & 0.021 & 0.016 & -0.016 & 0.032 & -0.020 & 0.024 & 0.023 & 0.019 \\
\hline $\mathrm{KCL}$ & 0.060 & 0.061 & -0.017 & 0.027 & -0.018 & 0.058 & 0.057 & 0.021 \\
\hline MRSN & 0.016 & 0.004 & -0.034 & 0.025 & -0.025 & 0.013 & 0.022 & 0.022 \\
\hline ONDKZM & 0.031 & 0.015 & -0.017 & 0.020 & -0.020 & 0.024 & 0.017 & 0.024 \\
\hline OSMNGZI & 0.019 & 0.009 & -0.015 & 0.023 & -0.018 & 0.019 & 0.014 & 0.023 \\
\hline PMKKL & 0.024 & 0.007 & -0.001 & 0.024 & 0.001 & 0.020 & 0.011 & 0.022 \\
\hline SCK & 0.023 & 0.010 & -0.033 & 0.010 & -0.033 & 0.023 & 0.033 & 0.028 \\
\hline TRY & 0.034 & 0.007 & -0.031 & 0.030 & -0.020 & 0.023 & 0.037 & 0.020 \\
\hline ULDG & 0.022 & 0.007 & -0.003 & 0.029 & -0.005 & 0.020 & 0.012 & 0.020 \\
\hline YZNCYL & 0.017 & 0.040 & -0.012 & 0.029 & -0.014 & 0.025 & 0.018 & 0.020 \\
\hline
\end{tabular}

Appendix-7: The Distances of Each Alternative from $A *$ and $A$ - and Closeness Coefficients

\begin{tabular}{|l|r|r|r|r|r|r|}
\hline & \multicolumn{3}{|c|}{$\mathbf{2 0 1 4}$} & \multicolumn{2}{|c|}{$\mathbf{2 0 1 5}$} \\
\hline & $\begin{array}{c}\text { The distance } \\
\text { of PIS }\end{array}$ & $\begin{array}{c}\text { The distance } \\
\text { of NIS }\end{array}$ & $\begin{array}{c}\text { Closeness } \\
\text { Coefficient }\end{array}$ & $\begin{array}{c}\text { The distance of } \\
\text { PIS }\end{array}$ & $\begin{array}{c}\text { The distance of } \\
\text { NIS }\end{array}$ & $\begin{array}{c}\text { Closeness } \\
\text { Coefficient }\end{array}$ \\
\hline AD & 0.102 & 0.051 & 0.405 & 0.121 & 0.040 & 0.249 \\
\hline AFYN & 0.094 & 0.083 & 0.414 & 0.089 & 0.100 & 0.530 \\
\hline AKNZ & 0.072 & 0.077 & 0.247 & 0.106 & 0.048 & 0.310 \\
\hline ATTRK & 0.060 & 0.111 & 0.596 & 0.068 & 0.107 & 0.609 \\
\hline ÇNNKL & 0.098 & 0.073 & 0.493 & 0.100 & 0.087 & 0.465 \\
\hline DCL & 0.082 & 0.074 & 0.487 & 0.052 & 0.117 & 0.694 \\
\hline DKZ & 0.100 & 0.045 & 0.344 & 0.104 & 0.050 & 0.325 \\
\hline EGE & 0.100 & 0.053 & 0.310 & 0.111 & 0.048 & 0.302 \\
\hline FRT & 0.081 & 0.092 & 0.595 & 0.082 & 0.095 & 0.535 \\
\hline GZ & 0.089 & 0.081 & 0.395 & 0.089 & 0.101 & 0.531 \\
\hline GZNTP & 0.087 & 0.062 & 0.464 & 0.076 & 0.080 & 0.515 \\
\hline HCTTP & 0.124 & 0.047 & 0.266 & 0.124 & 0.047 & 0.277 \\
\hline HRRN & 0.091 & 0.060 & 0.428 & 0.092 & 0.071 & 0.436 \\
\hline INN & 0.062 & 0.090 & 0.414 & 0.088 & 0.073 & 0.452 \\
\hline ISTNBL & 0.089 & 0.074 & 0.291 & 0.114 & 0.052 & 0.315 \\
\hline KCL & 0.089 & 0.079 & 0.448 & 0.106 & 0.062 & 0.368 \\
\hline KMSTC & 0.104 & 0.050 & 0.373 & 0.105 & 0.058 & 0.353 \\
\hline
\end{tabular}


Yönetim ve Ekonomi Araștırmaları Dergisi / Journal of Management and Economics Research Cilt/Volume: 15 Sayı/Issue: Özel Sayı 1/Special Issue 1 Aralık/December 2017 ss./pp. 155-176 N. Balcı Doi: http://dx.doi.org/10.11611/yead.373456

\begin{tabular}{|l|l|l|l|l|l|r|} 
KRKL & 0.070 & 0.106 & 0.392 & 0.087 & 0.072 & 0.451 \\
\hline KT & 0.115 & 0.066 & 0.464 & 0.076 & 0.106 & 0.583 \\
\hline MRSN & 0.105 & 0.054 & 0.219 & 0.110 & 0.055 & 0.332 \\
\hline ONDKZM & 0.076 & 0.080 & 0.422 & 0.087 & 0.070 & 0.445 \\
\hline OSMNGZI & 0.080 & 0.085 & 0.384 & 0.094 & 0.071 & 0.433 \\
\hline PMKKL & 0.074 & 0.100 & 0.359 & 0.083 & 0.091 & 0.522 \\
\hline SCK & 0.086 & 0.065 & 0.277 & 0.112 & 0.042 & 0.273 \\
\hline TRY & 0.113 & 0.044 & 0.245 & 0.099 & 0.060 & 0.378 \\
\hline ULDG & 0.077 & 0.092 & 0.417 & 0.084 & 0.088 & 0.512 \\
\hline YZNCYL & 0.083 & 0.073 & 0.545 & 0.074 & 0.085 & 0.532 \\
\hline
\end{tabular}

